www.jmscr.igmpublication.org Impact Factor 5.244

Index Copernicus Value: 83.27 ISSN (e)-2347-176x ISSN (p) 2455-0450 crossref DOI:_http://dx.doi.org/10.18535/jmscr/v4i8.37

Journal Of Medical Science And Clinical Research

\title{
A Prospective, Randomized, Double blinded, Comparative Study of Clonidine and Tramadol for Control of Shivering under Spinal Anesthesia
}

\author{
Authors \\ Dr Sowmya M Jois ${ }^{1}$, Dr Soumya Rao $^{2}$, Dr Krishna L S ${ }^{3}$, Dr A Sreenivasa Babu ${ }^{4}$ \\ ${ }^{1}$ Senior resident, ${ }^{2}$ Senior resident,${ }^{3}$ Consultant Anesthesiologist,${ }^{4}$ Head of Department \\ Department of Anesthesiology and Critical Care, The Bangalore Hospital, Bangalore, Karnataka, India \\ Email:drsowmyasharma@gmail.com ${ }^{(1)}$,saumyasrao@gmail.com ${ }^{(2), d r k r i s h n a l s @ y a h o o . c o . i n ~}{ }^{(3)}$ \\ Corresponding Author \\ Dr Sowmya M Jois
}

No 335, I Floor, 10th main Srinivasnagar, Bangalore, Karnataka, India

Email: drsowmyasharma@gmail.com

\begin{abstract}
BACKGROUND: Shivering is a common complication of spinal anesthesia. We compared the efficacy of intravenous clonidine and tramadol for the treatment of shivering under spinal anesthesia.

MATERIALS AND METHODS: In this prospective, randomised, double blinded, comparative study, 80 patients coming for lower abdominal and lower limb surgeries under spinal anesthesia were included. Patients were grouped into group $C$ and group $T$ who received clonidine $0.5 \mathrm{mcg} / \mathrm{kg}$ and tramadol $0.5 \mathrm{mg} / \mathrm{kg}$ respectively after the onset of shivering. Time of onset of shivering, cessation of shivering after administration of drug, vital signs and side effects were noted.

RESULTS: Time of cessation of shivering was shorter in group $C$ compared to group $T$ $(2.51 \pm 0.66$ minutes and mean time taken by Tramadol to control shivering was $4.82 \pm 0.90$ min). Group $C$ had more incidence of decrease in heart rate and blood pressure and higher sedation scores. Group Thad higher incidence of nausea and vomiting.

CONCLUSION: Our study concludes that both study drugs Clonidine and Tramadol are effective in controlling shivering under spinal anesthesia but clonidine took shorter time to achieve cessation of shivering compared to tramadol. There is a significant improvement in $\mathrm{SPO}_{2}$ values following control of shivering. Clonidine causes decrease in heart rate and systolic blood pressure. The occurrence of bradycardia, hypotension, dry mouth, sedation is higher in clonidine group. The occurrence of nausea and vomiting are higher in Tramadol group compared to clonidine group. Clonidine is safer and effective alternative to Tramadol in controlling shivering in patients receiving spinal anesthesia for surgery.

KEYWORDS-spinal, shivering, anesthesia, clonidine, tramadol
\end{abstract}

\section{INTRODUCTION}

Shivering is a common complication of modern anesthesia both under general and regional anesthesia. It is reported to be $40 \%$ to $70 \%$ of the patients undergoing surgery under regional anesthesia $^{(1,2)}$. The main causes of shivering intra and postoperatively are temperature loss, decreased sympathetic tone and systemic release of pyrogens $^{(3)}$. Hypothermia during neuraxial anesthesia develops initially from core to peripheral 
redistribution of body heat. Redistribution of body heat during spinal or epidural anesthesia typically decreases core body temperature 0.5-1.0 degree Celsius ${ }^{(4)}$. Shivering during regional anesthesia is preceded by core hypothermia and vasoconstriction above the level of the block. Shivering is usually defined as readily detectable fasciculation or tremor of the face, jaw, head trunk or extremities lasting longer than 15s. Perioperative shivering apart from patient discomfort is associated with a number of potentially deleterious squeal. These include increased oxygen consumption and carbon dioxide production, increased minute ventilation, catecholamine release, increased cardiac output, tachycardia and hypertension ${ }^{(5)}$. It is associated with increase in intraocular and intracranial pressure (6). It can be detrimental to patients with low cardiopulmonary reserve. It also interferes with monitoring and cause artefacts. It aggravates wound pain by stretching suture lines.

Intra and postoperative management of shivering are done by pharmacological and nonpharmacological methods. Non pharmacological methods are fluid warming, maintaining ambient temperature, surgical drapes, plastic bags, covering blankets and active warming devices. Pharmacological therapy has been found to offer a simple cost effective solution. Different drugs have been used in the past like opioids - morphine, fentanyl, pethidine ${ }^{(8)}$, $\operatorname{tramadol}^{(9),}$ butorphanol, Ketamine $^{(10)}$, Magnesium sulfate ${ }^{(11)}$, cholinomimetics and biogenic amines, 5-hydroxytryptamine receptor (5-HT3) antagonists ${ }^{(12)}, \alpha_{2}$ agonists Clonidine and Dexmedetomidine ${ }^{(13)}$, nefopam ${ }^{(14)}$ have been used.

In the quest for safe and efficacious drug in our study, we compared two easily available and safe drugs Clonidine and Tramadol for treating shivering in patient who received spinal anesthesia for various surgical procedures.

\section{METHODS}

This study was conducted in the department of Anesthesiology and Critical care, The Bangalore Hospital, Bangalore during the period from 2013 to
2014. This was a prospective, randomized, double blinded, comparative study. Based on literature survey for outcome variable of the present study, with $90 \%$ statistical power, 5\% Type I error, the sample size of 80 (each group with 40) patients was adequate. 80 patients who were to undergo elective abdominal and lower limb surgeries lasting less than 120 minutes under spinal anesthesia were selected and informed consent was obtained. After obtaining an approval by the ethics committee, patients who had given written and informed consent to participate in this study were included. Exclusion criteria included ASA III and above, emergency surgery, patients with hypersensitivity or contraindications for the drugs used in the study, history of significant cardiac, renal, hepatic, respiratory, psychological disorders, thyroid disorders, diabetic patients with autonomic neuropathy, patients who were taking medications like opioids, sedatives, vasodilators and other drugs that likely to cause alteration in thermoregulation, known history of alcohol or substance abuse, patient with present history of fever, use of blood and blood products intraoperatively or during immediate postoperative period.

A thorough pre-anesthetic evaluation was performed. After proper history and clinical examination, laboratory investigations (routine investigations like blood, urine, chest X-ray PA view, ECG, other relevant investigations E.g.: liver function tests etc) were reviewed.

All patients were kept nil per oral for solids for minimum of 6 hours and clear liquids for two hours. All of them received Tab Alprazolam $0.5 \mathrm{mg}$ at night and in the morning with sips of water.

The anesthesia management of the patients was standardized. Operating room temperature and recovery room temperature was maintained at 24 degree Celsius. All fluids and drugs administered were at room temperature. A large peripheral vein was cannulated, with 18 or 20 gauge intravenous catheter and secured. Ringer lactate drip was started, and patients were preloaded with $10 \mathrm{~mL} /$ $\mathrm{Kg}$. 
A mandatory monitoring comprising of ECG, pulse oximetry, non-invasive blood pressure and skin temperature probe to the axilla were attached. The baseline readings were recorded. Patients were positioned on the operating table either in the sitting or lateral position. Under asepsis, back was painted and draped. Skin over L2-L3 or L3-L4 was infiltrated with $2 \%$ lignocaine. Lumbar puncture was done with 25 gauge Quinke needle via midline approach. Injection Bupivacaine $0.5 \%$ hyperbaric was injected depending on the requirement of surgery $(2-4 \mathrm{~mL})$ after confirming free flow of cerebrospinal fluid. Patients were covered with single layer of drapes. Patients were administered 5 liters/ min of oxygen by simple face mask. Level of block was confirmed the level of sensory and motor blockade using loss of sensation to cold and modified Bromage scale respectively. Vital signs were monitored every $5 \mathrm{~min}$ in the first hour, and every $15 \mathrm{~min}$ in the next hour. Patients were monitored for total duration of 120 minutes.

Patients were meticulously observed for development of shivering. Patients who developed shivering intraoperatively or postoperatively for total duration of $120 \mathrm{~min}$ were included in the study. They were allocated to receive the drug intravenously at the onset of shivering by closed envelope method. The patients were blinded to the randomization. The two groups were as follows: Group $\mathrm{T}(\mathrm{no}=40)$ : received Tramadol $0.5 \mathrm{mg} / \mathrm{Kg}$ and Group C (no=40): received Clonidine $0.5 \mathrm{mcg} / \mathrm{Kg}$ The drugs were diluted to a volume of $5 \mathrm{~mL}$ and presented as coded syringes by anesthesiologists who were not involved in the management of patients.

The onset of shivering was monitored intraoperatively and postoperatively by the same anesthesiologist. Grading of shivering was done as per Wrench $^{(15)}$ as in table 1.

Shivering intraoperatively or postoperatively were considered to require treatment. Patients did not know which drug was being administered. The study drug was then administered slow intravenous as per the allocated group by anesthesiologist who was blind of the study drug.
TABLE 1: GRADE OF SHIVERING

\begin{tabular}{|l|l|}
\hline Grade & No shivering \\
\hline 0 & $\begin{array}{l}\text { one or more of the following: Piloerection } \\
\text { Peripheral vasoconstriction, peripheral cyanosis, } \\
\text { but without muscle activity }\end{array}$ \\
\hline 1 & $\begin{array}{l}\text { Visible muscle activity in confined to one muscle } \\
\text { group }\end{array}$ \\
\hline 3 & Visible muscle activity in more than one group \\
\hline 4 & Gross muscle activity involving the whole body \\
\hline
\end{tabular}

Time of administration of drug of the drug was noted. Time interval between test drug administration and cessation of shivering was noted. Response rate (shivering ceased after treatment in 15 minutes) was noted. If the shivering did not subside within 15 minutes, treatment was considered to be ineffective, and same additional dose of test drug was administered.

If the shivering recurred after the initial cessation of shivering, the test drug is repeated and other measures like covering blankets were taken. Duration of surgery was noted. Side effects like nausea, vomiting, bradycardia, hypotension, sedation score, dizziness and dryness of mouth was recorded. Sedation score was assessed with a four point scale as per Filos ${ }^{(16)}$ (Table 2)

\section{TABLE 2: SEDATION SCORE}

\begin{tabular}{|c|l|}
\hline Grade & \multicolumn{1}{|c|}{ Criteria } \\
\hline 1 & Awake and alert \\
\hline 2 & Drowsy, responsive to verbal stimuli \\
\hline 3 & Drowsy, arousable to physical stimuli \\
\hline 4 & Unarousable \\
\hline
\end{tabular}

Bradycardia $(<20 \%$ of baseline), hypotension $(<20 \%$ of baseline) and vomiting was treated with atropine, ephedrine and metoclopramide respectively, in titrated doses when required.

\section{STATISTICAL ANALYSIS}

Descriptive and inferential statistical analysis has been carried out in the present study. Student $t$ test (two tailed, independent) has been used to find the significance of study parameters on continuous scale between two groups (Inter group analysis) on metric parameters. Chi-square/ Fisher Exact test has been used to find the significance of study 
parameters on categorical scale between two or more groups. The Statistical software namely SAS 9.2, SPSS 15.0, Stata 10.1, MedCalc 9.0.1, Systat 12.0 and $\mathrm{R}$ environment ver.2.11.1 were used for the analysis of the data and Microsoft word and Excel have been used to generate graphs, tables etc. Suggestive significance ( $\mathrm{P}$ value: $0.05<\mathrm{P}<0.10$ )* moderately significant ( $\mathrm{P}$ value: $0.01<\mathrm{P} \leq 0.05$ ) $* *$ strongly significant $(\mathrm{P}$ value: $\mathrm{P} \leq 0.01)$

\section{RESULTS}

There were no statistically significant differences between the two groups in terms of demographic characteristics namely age, sex, weight, ASA status, duration of surgery and grade of shivering as shown in table 3 .

\section{TABLE} 3:

DEMOGRAPHIC

CHARACTERISTICS

\begin{tabular}{|l|l|l|l|}
\hline Group & $\mathrm{C}$ & $\mathrm{T}$ & $\begin{array}{l}\mathrm{P} \\
\text { value }\end{array}$ \\
\hline Mean age in years & $42.25 \pm 12.38$ & $38.60 \pm 12.34$ & $>0.05$ \\
\hline Male / female & $21 / 19$ & $20 / 20$ & $>0.05$ \\
\hline Weight(kg) of & $66.70 \pm 12.57$ & $69.15 \pm 12.06$ & $>0.05$ \\
\hline $\begin{array}{l}\text { Duration of } \\
\text { surgery(minutes) }\end{array}$ & $23 / 17$ & $68.70 \pm 17.37$ & $>0.05$ \\
\hline ASA I/II & $35.03 \pm 22.57$ & $33.05 \pm 21.42$ & $>0.05$ \\
\hline $\begin{array}{l}\text { Onset } \\
\text { shivering(minutes) }\end{array}$ & $23 / 17$ & $22 / 18$ & $>0.05$ \\
\hline $\begin{array}{l}\text { Grade of shivering } \\
\text { III/ IV }\end{array}$ & & \\
\hline
\end{tabular}

TABLE 4: RESPONSE RATE

\begin{tabular}{|l|l|l|l|l|}
\hline \multirow{2}{*}{ Response } & \multicolumn{2}{l|}{$\begin{array}{l}\text { Clonidine } \\
\text { Group }\end{array}$} & \multicolumn{2}{l|}{$\begin{array}{l}\text { Tramadol } \\
\text { Group }\end{array}$} \\
\cline { 2 - 5 } & No & $\%$ & No & $\%$ \\
\hline Shivering controlled & 38 & 95.0 & 37 & 92.5 \\
\hline $\begin{array}{l}\text { Shivering not } \\
\text { controlled }\end{array}$ & 2 & 5.0 & 3 & 7.5 \\
\hline Total & 40 & 100.0 & 40 & 100.0 \\
\hline
\end{tabular}

As shown in table 4, 38 out of 40 patients $(95 \%)$ in clonidine group and 37 out of 40 patients $(92.5 \%)$ tramadol group had cessation of shivering after test drug administration. Response rate was higher in clonidine group compared to tramadol group but it was not statistically significant with $\mathrm{p}=0.64$.
TABLE 4: COMPARISON OF SUCCESS, FAILURE AND RECCURENCE IN TWO GROUPS

\begin{tabular}{|l|l|l|l|l|}
\hline \multirow{2}{*}{ RESPONSE } & \multicolumn{2}{|l|}{$\begin{array}{l}\text { Clonidine } \\
\text { Group } \\
(\mathrm{n}=40)\end{array}$} & \multicolumn{2}{l|}{$\begin{array}{l}\text { Tramadol } \\
\text { Group } \\
(\mathrm{n}=40)\end{array}$} \\
\cline { 2 - 5 } & No & $\%$ & No & $\%$ \\
\hline Nil & 36 & 90.0 & 32 & 80.0 \\
\hline Yes & 4 & 10.0 & 8 & 20.0 \\
\hline $\begin{array}{l}\text { Failure of drug to } \\
\text { decrease shivering }\end{array}$ & 2 & 5.0 & 3 & 7.5 \\
\hline Recurrence of shivering & 2 & 5.0 & 5 & 12.5 \\
\hline
\end{tabular}

As shown in table 4, shivering did not subside after test drug administration in 3 patients of tramadol group and 2 patients in clonidine group $(\mathrm{P}=0.97) .5$ patients in tramadol group and 2 patients in clonidine group had recurrence of shivering after initial cessation of shivering $(\mathrm{P}=0.24)$

TABLE 5: COMPARISON OF TIME AND CESSATION OF SHIVERING

\begin{tabular}{|l|l|l|l|l|}
\hline \multirow{2}{*}{$\begin{array}{l}\text { Time taken } \\
\text { (minutes) }\end{array}$} & \multicolumn{2}{l|}{$\begin{array}{l}\text { Clonidine } \\
\text { Group }\end{array}$} & \multicolumn{2}{l|}{$\begin{array}{l}\text { Gramadol } \\
\text { Group }\end{array}$} \\
\cline { 2 - 5 } & No & $\%$ & No & $\%$ \\
\hline $1-2$ & 10 & 25.0 & 0 & 0.0 \\
\hline $2-4$ & 27 & 67.5 & 9 & 22.5 \\
\hline $4-6$ & 1 & 2.5 & 28 & 70.0 \\
\hline Failure & 2 & 5.0 & 3 & 7.5 \\
\hline Total & 40 & 100.0 & 40 & 100.0 \\
\hline Mean \pm SD & $2.51 \pm 0.66$ & $4.82 \pm 0.90$ \\
\hline
\end{tabular}

Mean time taken in group $\mathrm{C}$ from clonidine administration to cessation of shivering was $2.51 \pm 0.66$ minutes. Mean time taken from tramadol administration and cessation of shivering was $4.82 \pm 0.90$ minutes. Time taken by clonidine to control shivering was less compared to tramadol with $\mathrm{P}<0.001^{* *}$ as shown in table 5 and figure 1.

\section{FIGURE 1}

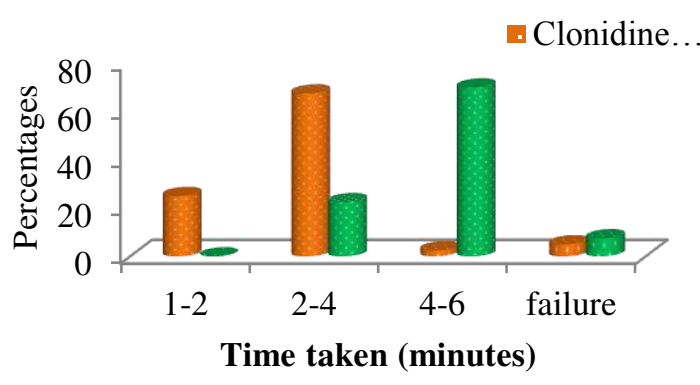


TABLE6: COMPARISON OF HEART RATE

\begin{tabular}{|l|l|l|l|}
\hline Heart rate (bpm) & $\begin{array}{l}\text { Clonidine } \\
\text { Group }\end{array}$ & $\begin{array}{l}\text { Tramadol } \\
\text { Group }\end{array}$ & P value \\
\hline Baseline HR & $83.55 \pm 10.87$ & $81.93 \pm 11.09$ & 0.510 \\
\hline $\begin{array}{l}\text { HR 5 min after } \\
\text { subarachnoid } \\
\text { block }\end{array}$ & $74.80 \pm 10.26$ & $76.80 \pm 11.61$ & 0.417 \\
\hline $\begin{array}{l}\text { HR during } \\
\text { shivering }\end{array}$ & $75.50 \pm 9.45$ & $79.00 \pm 11.62$ & 0.143 \\
\hline $\begin{array}{l}\text { HR after 15 min } \\
\text { of injection }\end{array}$ & $71.60 \pm 10.83$ & $80.45 \pm 11.67$ & $0.001^{* *}$ \\
\hline
\end{tabular}

As depicted in table 6, basal heart rate, heart rate after subarachnoid block and heart rate during shivering were not statistically significant. There was decrease in mean heart rate after clonidine injection in group $\mathrm{C}$ compared to tramadol group which was statistic ally significant $\mathrm{p}<0.001^{* *}$.

\section{TABLE 7: COMPARISON OF SYSTOLIC BLOOD PRESSURE}

\begin{tabular}{|l|l|l|l|}
\hline SBP (mm Hg) & $\begin{array}{l}\text { Clonidine } \\
\text { Group }\end{array}$ & $\begin{array}{l}\text { Tramadol } \\
\text { Group }\end{array}$ & P value \\
\hline Baseline values & $122.60 \pm 9.61$ & $120.6 \pm 10.28$ & 0.371 \\
\hline $\begin{array}{l}5 \quad \text { min after } \\
\text { subarachnoid } \\
\text { block }\end{array}$ & $101.18 \pm 8.57$ & $103.88 \pm 9.80$ & 0.193 \\
\hline $\begin{array}{l}\text { SBP during } \\
\text { shivering }\end{array}$ & $111.29 \pm 11.17$ & $107.03 \pm 8.99$ & $0.067+$ \\
\hline $\begin{array}{l}\text { SBP after 15 min } \\
\text { of injection }\end{array}$ & $107.58 \pm 10.65$ & $113.9 \pm 9.77$ & $0.007 * *$ \\
\hline
\end{tabular}

As shown in table 7, there was no difference in baseline systolic blood pressure, systolic blood pressure after spinal and SBP during shivering between two groups. Systolic blood pressure was less in clonidine group compared to tramadol group after clonidine administration which was statistically significant $(\mathrm{p}=0.007 * *)$.

As shown in table 8, the difference between baseline diastolic blood pressure, DBP after subarachnoid block, DBP during shivering and DBP after test drug administration was not statistically significant.
TABLE 8: COMPARISON OF DIASTOLIC BLOOD PRESSURE

\begin{tabular}{|l|l|l|l|}
\hline DBP (mm Hg) & $\begin{array}{l}\text { Clonidine } \\
\text { Group }\end{array}$ & $\begin{array}{l}\text { Tramadol } \\
\text { Group }\end{array}$ & P value \\
\hline Baseline values & $72.28 \pm 9.08$ & $72.43 \pm 9.24$ & 0.942 \\
\hline $\begin{array}{l}\text { DBP after } \\
\text { subarachnoid } \\
\text { block }\end{array}$ & $59.93 \pm 10.60$ & $63.63 \pm 7.95$ & $0.081+$ \\
\hline $\begin{array}{l}\text { DBP during } \\
\text { shivering }\end{array}$ & $63.14 \pm 10.15$ & $64.68 \pm 7.10$ & 0.434 \\
\hline $\begin{array}{l}\text { DBP after 15 } \\
\text { min of injection }\end{array}$ & $63.15 \pm 7.38$ & $64.40 \pm 6.58$ & 0.427 \\
\hline
\end{tabular}

TABLE 9: COMPARISON OF SPO $2 \%$ IN TWO GROUPS STUDIED

\begin{tabular}{|l|l|l|l|}
\hline SPO2\% & $\begin{array}{l}\text { Clonidine } \\
\text { Group }\end{array}$ & $\begin{array}{l}\text { Tramadol } \\
\text { Group }\end{array}$ & P value \\
\hline $\begin{array}{l}\text { Baseline } \\
\text { values }\end{array}$ & $100.00 \pm 0.00$ & $99.93 \pm 0.27$ & $0.079+$ \\
\hline $\begin{array}{l}\text { SPO2 5 min } \\
\text { after spinal }\end{array}$ & $100.00 \pm 0.00$ & $100.00 \pm 0.00$ & 1.000 \\
\hline $\begin{array}{l}\text { SPO2 during } \\
\text { shivering }\end{array}$ & $98.525 \pm 1.61+$ & $98.87 \pm 1.20$ & 0.26 \\
\hline $\begin{array}{l}\text { SPO2 after 15 } \\
\text { min of } \\
\text { injection }\end{array}$ & $99.80 \pm 0.46$ & $99.80 \pm 0.41$ & 1.000 \\
\hline
\end{tabular}

As depicted in table 9 the difference between two groups in baseline oxygen saturation, saturation during shivering and saturation after 15 minutes of injection is not statistically significant.

TABLE 10: COMPARISON OF TEMPERATURE IN TWO GROUPS OF PATIENTS STUDIED

\begin{tabular}{|l|l|l|l|}
\hline Temperature & $\begin{array}{l}\text { Clonidine } \\
\text { Group }\end{array}$ & $\begin{array}{l}\text { Tramadol } \\
\text { Group }\end{array}$ & P value \\
\hline Baseline values & $36.89 \pm 0.30$ & $36.98 \pm 0.35$ & 0.249 \\
\hline $\begin{array}{l}\text { Temperature after } \\
\text { spinal block }\end{array}$ & $36.67 \pm 0.31$ & $36.8 \pm 0.34$ & $0.060+$ \\
\hline $\begin{array}{l}\text { Temperature during } \\
\text { shivering }\end{array}$ & $36.50 \pm 0.30$ & $36.63 \pm 0.33$ & 0.070 \\
\hline $\begin{array}{l}\text { Temp after 15 min } \\
\text { of injection }\end{array}$ & $36.45 \pm 0.28$ & $36.53 \pm 0.35$ & 0.260 \\
\hline
\end{tabular}

As shown in table 10, the difference between baseline temperature, temperature after subarachnoid block, temperature during shivering and temperature after test drug administration between two groups was not statistically significant. 
TABLE 11: COMPARISON OF SIDE EFFECTS

\begin{tabular}{|c|l|l|l|l|}
\hline \multirow{2}{*}{ Side effects } & \multicolumn{2}{l|}{$\begin{array}{l}\text { Clonidine } \\
\text { Group } \\
(\mathrm{n}=40)\end{array}$} & \multicolumn{2}{l|}{$\begin{array}{l}\text { Tramadol } \\
\text { Group } \\
(\mathrm{n}=40)\end{array}$} \\
\cline { 2 - 6 } & No & $\%$ & No & $\%$ \\
\hline \multicolumn{1}{|c|}{ Nil } & 30 & 75.0 & 34 & 85.0 \\
\hline \multicolumn{1}{|c|}{ Yes } & 10 & 25.0 & 6 & 15.0 \\
\hline Bradycardia & 4 & 10.0 & 1 & 2.5 \\
\hline Dizziness & 0 & 0.0 & 5 & 12.5 \\
\hline Dry mouth & 2 & 5.0 & 0 & 0.0 \\
\hline Hypotension & 4 & 10.0 & 0 & 0.0 \\
\hline Sedation score 1 & 31 & $77.5 \%$ & 36 & $90 \%$ \\
& 9 & $22.5 \%$ & 4 & $10 \%$ \\
\hline
\end{tabular}

FIGURE 2

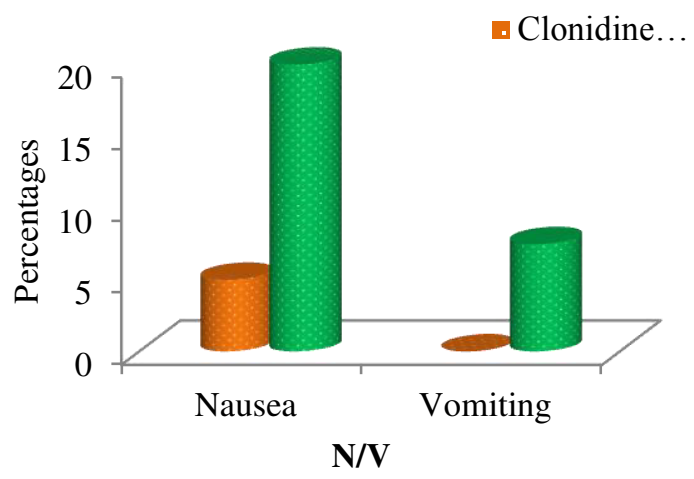

FIGURE 3

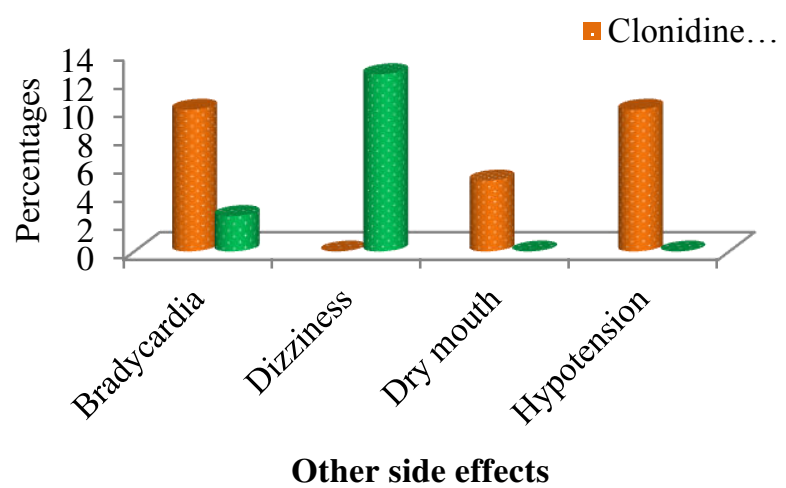

As shown in table 11, figure 2 and 3, 4 patients in clonidine group $(10 \%)$, and one patient in tramadol group L(2.5\%) had bradycardia requiring treatment. 5 patients in tramadol group $(12.5 \%)$ and none in clonidine group had dizziness. 2 patients of clonidine group had dry mouth and 4 patients of clonidine group had hypotension.

\section{DISCUSSION}

Shivering is an involuntary, oscillatory muscular activity that augments metabolic heat production. Vigorous shivering increases metabolic heat production up to $600 \%$ above basal level. Neuraxial anesthesia inhibits numerous aspects of thermoregulatory control. The vasoconstriction and shivering thresholds are reduced by regional anesthesia and further reduced by adjuvant drugs and advanced age. Even once triggered, the gain and maximum response intensity of shivering are about half-normal. Finally, behavioural thermoregulation is impaired.

The result is that cold defences are triggered at a lower temperature than normal during regional anesthesia, Defences are less effective once triggered, and patients frequently do not recognize that they are hypothermic. Because core temperature monitoring remains rare during regional anesthesia, substantial hypothermia often goes undetected in these patients.

Shivering can be controlled using a combination of non-pharmacological and pharmacological methods. Non pharmacological methods to prevent heat loss include blankets, warm operation theatre, and warm intravenous fluids. Pharmacological methods to treat shivering include pethidine, tramadol, nefopam, fentanyl etc

Our study was designed to compare efficacy of clonidine, an alpha agonist with that of tramadol, a non-opioid analgesic for control of shivering after spinal anesthesia in patients undergoing various surgeries under spinal anesthesia.

Clonidine is a mixed alpha-1 and alpha-2 adrenoceptor agonist with a predominant alpha-2 action (220:1 $\alpha 2$ to $\alpha 1)$. Traditionally, it has been used as an antihypertensive agent since the late sixties. Its primary effect is sympatholysis and it reduces peripheral norepinephrine release by stimulation of the prejunctional inhibitory alpha-2 adrenoceptors. Clonidine exerfts its antishivering effects at three levels: Hypothalmus, locus coeruleus and spinal cord. At the hypothalamic level, it decreases thermoregulatory threshold for vasoconstriction and shivering, because 
hypothalamus has high density of alpha 2 adrejnorceptores and hence is effective in treating the established post anaesthetic shivering. It also reduces spontaneous firing in locus coeruleus - a proshivering centre in pons. At the spinal cord level, it activates the alpha 2 adreno receptors, and release of dynorphine, norepinephrine and acetylcholine ${ }^{(17) .}$ Tramadol is a synthetic 4-phenyl-piperidine analog of codeine. Tramadol stimulates the $\mu$-receptor and, to a lesser extent, the $\delta$ - and $\kappa$-opioid receptors. Tramadol is an opioid analgesic with opioid action preferably mediated via $\mu(\mathrm{mu})$ receptor with minimal effect on kappa and delta binding sites; tramadol also activates the mononergic receptor of the descending neuraxial inhibiting pain pathway. The anti-shivering action of Tramadol is probably mediated via its opioid or serotonergic and noradrenergic activity or both.

The aim of our study was to compare the relative efficacy of intravenously administered Tramadol $0.5 \mathrm{mg} / \mathrm{kg}$ against $0.5 \mu \mathrm{g} / \mathrm{kg}$ Clonidine to control shivering in patients who receive spinal anesthesia for various procedures and to study the side effects of the study drugs in terms of sedation, hypotension, nausea and vomiting and others.

The demographic data that includes the age, sex, weight, ASA physical status, and type of surgery and duration of surgery that were conducted on patients under the study group were almost identical and did not attract statistical differences.

There was no statistically significant difference with respect to basal heart rate, systolic blood pressure, diastolic blood pressure, axillary temperature and oxygen saturation between the two groups.

In the present study, the onset of shivering was comparable in both Group C (35.03 \pm 22.57 minutes) and Group $\mathrm{T}(33.05 \pm 21.42$ minutes $)$ with $\mathrm{P}=0.689$. So time for onset of shivering and severity of shivering were not statistically different between the two groups.

In the present study, mean time taken by Clonidine to control shivering was $2.51 \pm 0.66$ minutes and mean time taken by Tramadol to control shivering was $4.82 \pm 0.90 \mathrm{~min}$. So, it was observed that clonidine is as effective as tramadol in treating post spinal shivering, but the time interval from the commencement of treatment to cessation of shivering is quite less with clonidine than with tramadol $\quad(p<0.001)$. The response rate was also higher in the clonidine group than in tramadol group but difference was not statistically significant.

We found that both Clonidine and Tramadol are effective in controlling shivering under spinal anesthesia. Previous studies investigating the antishivering role of clonidine and tramadol have shown similar results as our study. Wason $\mathrm{R}$ et al found that clonidine $75 \mathrm{mcg} / \mathrm{kg}$ and tramadol $0.5 \mathrm{mg} / \mathrm{kg}$ i.v prophylactically just before neuraxial blockade significantly decreased the incidence of shivering without causing any major side effect ${ }^{(18)}$. In a prospective double-blind randomized controlled clinical trial in 80 ASA I patients under spinal anesthesia done by Shukla U and coworkers ${ }^{(17)}$, the mean interval between the injection of drug (clonidine $0.5 \mathrm{ncg} / \mathrm{Kg}$ and tramadol $0.5 \mathrm{mg} / \mathrm{kg}$ ) and complete cessation of shivering was $2.54 \pm 0.76$ and $5.01 \pm 1.02$ minutes, respectively which was similar to our study. Kulshrestha and coworkers ${ }^{(19)}$ did a double blinded comparative study on 90 ASA I and II scheduled for elective LSCS under spinal anesthesia. Those who subsequently developed shivering intra operatively received either clonidine $50 \mu \mathrm{g}$ or tramadol $50 \mathrm{mg}$. The time interval from the commencement of treatment to cessation of shivering is quite less with clonidine (2.59 \pm $0.66 \mathrm{~min})$ than with tramadol $(5.11 \pm 0.08 \mathrm{~min})(\mathrm{p}>$ 0.0001). This was consistent with our study.

In our study we found that the side effects were found to be more with tramadol group. As depicted in table 17 and figure 18 incidence of nausea was $20 \%$ in tramadol group compared to $5 \%$ in clonidine group. Incidence of vomiting in tramadol group was $7.5 \%$ compared to none in clonidine group.

Incidence of nausea was higher in tramadol group compared with clonidine group. Incidence of vomiting was higher with tramadol group compared to clonidine group. Incidence of nausea and vomiting is significantly less in Clonidine group compared to Tramadol group with $\mathrm{p}=0.013^{*}$. 
Systolic blood pressure was less in the group C compared to group $\mathrm{T}$ after test drug administration which was statistically significant $(p=0.007)$ but there was no difference in diastolic blood pressure between the groups

5 out of 40 patients in tramadol group complained of dizziness which was not seen with Clonidine group. In our study, bradycardia occurred in 4 patients in Clonidine group and 1 patient in Tramadol group. 4 patients in Clonidine group had hypotension compared to none in Tramadol group. Incidence of bradycardia and hypotension was more in clonidine group compared to tramadol group.

In our study we found that the patients who received clonidine were more sedated than patients in the tramadol group. 9 out of 40 patients in clonidine group had grade 2 shivering which is $22.5 \%$. 4 out of 40 patients in tramadol group had grade 2 shivering which is $10.0 \%$. No patient in either group had sedation of grade 3 or grade 4 .

2 patients who received clonidine had dry mouth which was not seen with tramadol.

On overall analysis, higher complication rate were noted in group $\mathrm{T}$ patients compared to group $\mathrm{C}$.

Five patients of group $\mathrm{T}$ had recurrence of shivering $(12.5 \%)$, while 2 patients in clonidine group suffered recurrence $(5 \%)$ as in table -----These patients received repeat dose of same drug after which there was cessation of shivering.

3 patients in tramadol group $(7.5 \%)$ and 2 patients in clonidine group (5\%) had failure of drug to decrease shivering as shown in table---. Failure rate was more in Group $\mathrm{T}$ compared to Group $\mathrm{C}$ though the difference was not statistically significant

\section{CONCLUSION}

Our study concludes that both study drugs Clonidine and Tramadol are effective in controlling shivering under spinal anesthesia but clonidine took shorter time to achieve cessation of shivering compared to tramadol. There is a significant improvement in SPo2 values following control of shivering though it was not statistically significant. Clonidine causes decrease in heart rate and systolic blood pressure. The occurrence of bradycardia, hypotension, dry mouth, sedation is higher in clonidine group. The occurrence of nausea and vomiting are higher in Tramadol group compared to clonidine group. Clonidine is safer and effective alternative to Tramadol in controlling shivering in patients receiving spinal anesthesia for surgery.

A limitation of our study is that we did not measure core body temperature. To measure core body temperature nasopharyngeal, esophageal, tympanic or rectal temperature probe must have been used.

We have not included patients of extremes of age. Study could have included pediatric and elderly population.

\section{ACKNOWLEDGEMENT}

We extend our gratitude towards participants of the study.

Conflict of interest: nil

Source of support: None

\section{REFERENCES}

1. De Whitte, Sessler DI. Perioperative shivering: Physiology and Pharmacology. Anaesthesiology.2002; 96:467-84.

2. Sessler DI, Ponte J. Shivering during epidural anaesthesia. Anesthesiology. 1990; 72:816-21.

3. Sessler DI. Perioperative heat balance. Anaesthesiology. 2000; 92:578-96.

4. Larry J .Crowley, Donal J. Buggy. Shivering and neuraxial anesthesia. Regional anesthesia and pain medicine volume 33 no 3 may- June 2008:241-252.

5. Buggy.D.J and Crossley W.A. Thermoregulation, mild perioperature hypothermia and post-anesthetic shivering. BJA 84(5):615-28 (2000)

6. Bhattacharya P., Bhattacharya L., Jain R., Agarwal R. Post anaesthesia shivering (pas): a review. Indian J. anaesth. 2003; 47 (2) : 88-93

7. Daniel I. Sessler. Temperature Regulation and Monitoring. In: Miller RD, Eriksson IL, Fleisher LA, Wiener-Kronish PJ, Young LW (eds.)Miller's Anesthesia. 7th ed. 
Philadelphia: Churchill Livingstone Elsevier; 2010. $p$

8. Pauca AL, Savage RT, Simpson S Roy RC. Effect of pethidine, fentanyl and morphine on post-operative shivering in man. Acta Anesthesiol Scand 1984; 28(2):138-43.

9. Bansal P, Jain G.Control of shivering with clonidine, butorphanol, and tramadol under spinal anesthesia: a comparative study. Local Reg Anesth. 2011; 4:29-34

10. D. Dal, A. Kose, M. Honca, S. B. Akinci, E. Basgul and U. Aypar; Efficacy of prophylactic ketamine in preventing postoperative shivering BJA 2005; 95(2):189-192

11. Wadhwa A, Sengupta P, Durrani J, Akça O, R Lenhardt, D I Sessler, A G Doufas. Magnesium sulphate only slightly reduces the shivering threshold in humans British Journal of Anaesthesia 2005; 94: 756-762.

12. Powell RM, Buggy DJ. Ondansetron given before induction of anesthesia reduces shivering after general anesthesia. Anesth Analg. 2000; 90:1423-7.

13. Elvan EG, Oc B, Uzun S, Karabulut E, Coşkun F, Aypar U. Dexmedetomidine and postoperative shivering in patients undergoing elective abdominal hysterectomy. Eur J Anaesthesiol. 2008; 25:357-64

14. F. Bilotta,1 F. Ferri,1 F. Giovannini,1 G. Pinto2 and G. Rosa Nefopam or clonidine in the pharmacologic prevention of shivering in patients undergoing conscious sedation for interventional neuroradiology. Anaesthesia, 2005, 60, pages 124-128

15. Wrench IJ, Cavill G, Ward JE, Crossley AW. Comparison between Alfentanil, Pethedine, and placebo in the treatment of postoperative shivering. Br J Anaesth. 1997; 79:541-2.

16. Filos KS, Goudas LC, Patroni O, Polyzou V. Hemodynamic and analgesic profile after intrathecal clonidine in humans. A dose- response study. Anesthesiology. 1994; 81:591-601.

17. Shukla U, Malhotra K, Prabhakar T. A comparative study of the effect of clonidine and tramadol on post-spinal anaesthesia shivering. Indian J Anaesth 2011;55:242-6

18. Wason R, Jain N, Gupta P, Gogia AR. Randomized double-blind comparison of prophylactic ketamine, clonidine and tramadol for the control of shivering under neuraxial anaesthesia. Indian $\mathrm{J}$ Anaesth 2012; 56:370-5

19. S. Kulshrestha, R.K. Mehta. Efficacy of Intravenous Clonidine \& Tramadol on Post Spinal Anaesthesia Shivering in Elective Lower Segment Caesarean Section: A Randomized Comparative Study. People's Journal of Scientific Research Vol. 7(1), Jan. 2014 